\title{
FORMULASI OBAT KUMUR HERBAL EKSTRAK ETANOL KULIT BUAH NANAS (Ananas comosus (L.) Merr.) SEBAGAI ANTIBAKTERI Streptococcus sanguinis PENYEBAB PLAK GIGI
}

\author{
Triyani Sumiati*1 $^{*}$ Eem Masaenah ${ }^{2}$, Khamim Nasrudin Mustofa ${ }^{3}$ \\ ${ }^{123}$ Program Studi S1 Farmasi, Sekolah Tinggi Teknologi Industri dan Farmasi Bogor \\ Korespondensi: *triyanisumiati@gmail.com
}

\begin{abstract}
ABSTRAK
Kulit buah nanas diketahui mengandung senyawa aktif flavonoid dan tanin serta berkhasiat sebagai zat antibakteri. Tujuan dari penelitian ini adalah membuat formulasi sediaan obat kumur herbal dari ekstrak etanol kulit buah nanas serta melakukan pegujian aktivitas antibakterinya terhadap pertumbuhan bakteri Streptococcus sanguinis penyebab plak gigi. Ekstrak kulit nanas didapatkan dari hasil ekstraksi menggunakan pelarut etanol 96\%. Metode uji difusi cakram dilakukan dengan tujuan mengetahui potensi penghambatan bakteri pada sediaan obat kumur herbal ekstrak etanol kulit buah nanas. Pada penelitian ini dilakukan pengukuran aktivitas antibakteri pada 3 kelompok perlakuan dengan masing-masing konsentrasi 30\%, 40\%, dan 50\%. Hasil penelitian menunjukkan bahwa ekstrak kulit buah nanas dapat diformulasikan menjadi sediaan obat kumur. Sediaan obat kumur ekstrak kulit nanas memiliki aktivitas antibakteri terhadap bakteri Streptococcus sanguinis pada semua konsentrasi. Aktivitas antibakteri terbesar dan termasuk kategori kuat pada konsentrasi $50 \%$ dengan nilai rata-rata diameter zona bening sebesar 15,03 $\mathrm{mm}$ pada ekstrak kulit buah nanas dan 12,51 mm. Evaluasi pada sediaan obat kumur ekstrak etanol kulit buah nanas telah memenuhi persyaratan dan stabil selama penyimpanan.
\end{abstract}

Kata Kunci : Antibakteri, kulit nanas, obat kumur, Streptococcus sanguinis

\begin{abstract}
Pineapple peel is known to contain active compounds of flavonoids and tannins and has antibacterial properties. The purpose of this study was to formulate herbal mouthwash preparations from ethanol extract of pineapple rind and to test its antibacterial activity against the growth of Streptococcus sanguinis bacteria that causes dental plaque. Pineapple peel extract is obtained from the extraction using $96 \%$ ethanol as a solvent. The disc diffusion test method was carried out in order to determine the potential inhibition of bacteria in the herbal mouthwash preparation of the ethanol extract of pineapple rind. In this study, antibacterial activity was measured in 3 treatment groups with concentrations of $30 \%, 40 \%$, and $50 \%$ respectively. The results showed that the pineapple peel extract can be formulated into a mouthwash. Pineapple peel extract mouthwash has antibacterial activity against Streptococcus sanguinis at all concentrations. The largest antibacterial activity was in the strong category at a concentration of 50\% with an average value of the clear zone diameter of $15.03 \mathrm{~mm}$ in the extract of pineapple rind and $12.51 \mathrm{~mm}$. Evaluation on the ethanol extract of pineapple peel mouthwash has met the requirements and is stable during storage.
\end{abstract}

Keywords: Antibacterial, pineapple peel, mouthwash, Streptococcus sanguinis 


\section{PENDAHULUAN}

Nanas (Ananas comosus (L.) Merr) merupakan tumbuhan tropis dengan struktur anatomi tanaman yang bersemak. Dari berbagai penelitian yang telah dilakukan diketahui bahwa berbagai senyawa kimia penting terkandung dalam buah nanas baik untuk kesehatan manusia diantaranya mineral, glukosa, fruktosa, sukrosa, vitamin $\mathrm{C}$, senyawa fenolik dan flavonoid. ( $\mathrm{Lu}$ et al., 2014).

Buah nanas telah dibuat berbagai produk olahan dan dari hasil olahan ini akan menyisakan limbah yaitu berupa kulit nanas. Berbagai senyawa penting terdapat dalam kulit buah nanas yaitu: air, serat kasar, karbohidrat, protein, gula pereduksi, flavonoid, dan tanin (Nuraini, 2011). Ekstrak etanol kulit nanas mempunyai daya penghambatan terhadap pertumbuhan bakteri Staphylococcus aureus dan Eschericia coli Berdasarkan penelitian tersebut diperoleh bahwa senyawa flavonoid pada ekstrak kulit nanas yang mempunyai aktivitas antibakteri. (Setiawan, 2015). Ekstrak kulit nanas pada konsentrasi $25 \%$ diketahui mempunyai aktivitas antibakteri dalam kategori kuat terhadap Streptococcus mutans (Annisa, 2015).

Dari berbagai penelitian diketahui bahwa salah satu bakteri yang sering tumbuh dan berkembang biak pada mulut manusia adalah Streptococcus sanguinis yang berbentuk coccus dan termasuk ke dalam kelompok bakteri. Bakteri ini dapat menyebabkan terjadinya plak gigi. Plak gigi dapat terbentuk akibat adanya lengketan yang terbentuk serta berisi bakteri pada semua permukaan gigi. Bakteri ini Mekanisme kerja dari bakteri Streptococcus sanguinis adalah dapat merubah sukrosa menjadi asam melalui proses fermentasi yang menyebabkan terjadinya $\mathrm{pH}$ asam pada permukaan gigi dan hal ini akan menghilangkan mineral pada gigi. Streptococcus sanguinis ini dapat menyebabkan suatu infeksi akibat terjadinya penetrasi bakteri di dalam mulut ke dalam darah (Yamaguchi et al., 2006).

Berbagai upaya dilakukan untuk mencegah terjadinya kerusakan gigi oleh bakteri Streptococcus sanguinis. Pencegahan terjadinya kerusakan pada gigi dapat dilakukan melalui penghambatan pertumbuhan plak gigi dengan cara membersihkannya secara teratur (Silva et al., 2004). Untuk membersihkan gigi dapat dilakukan dengan menggosok gigi dan berkumur. Obat kumur adalah larutan yang mengandung air dan banyak digunakan untuk menghilangkan bau kurang sedap pada mulut, sebagai penyegar, dan untuk menghilangkan plak. Keuntungan pengguanan obat kumur karena larutan obat kumur dapat membersihkan sampai ke sela-sela gigi sehingga dapat lebih efektif membersihkan kotoran dan plak yang menenpel pada permukaan gigi. (Padmono et al., 2013). Sampai saat ini belum ada formulasi obat kumur yang berasal dari ekstrak kulit nanas. Oleh karena itu, maka pada penelitian ini akan dibuat formulasi ekstrak etanol kulit nanas dan selanjutnya dilakukan pengujian aktivitas antibakteri terhadap bakteri Streptococcus sanguinis.

\section{METODOLOGI PENELITIAN}

Bahan: Kulit nanas yang diperoleh dari Kabupaten Subang, bakteri Streptococcus sanguinis yang diperoleh dari Laboratorium Mikrobiologi Fakultas Farmasi Universitas Sumatera Utara, etanol 96\%, Nutrient Agar (Merck Millipore), Nutrient Broth (Himedia), asam klorida $2 \mathrm{~N}$, pereaksi Bouchardat, pereaksi Dragendrof, $\mathrm{FeCl}_{3}, \mathrm{NaOH}$, asam klorida pekat, asam asetat anhidrat, asam sulfat pekat, kloroform, natrium sulfat anhidrat, metanol, pereaksi Molish, akuades, mentol, natrium benzoat, gliserin, etanol 95\%, natrium bikarbonat, natrium sakarin, chlorhexidine base, obat kumur komersial.

Alat: Cawan petri, neraca digital Sartorius BSA2245, autoklaf YX-280B, oven Memmert, Laminary Air Flow (LAF), alat-alat gelas (pyrex), ayakan 60 mesh, cawan porselin, desikator Duran, cawan penguap, rotary vacum evaporator Ika RV 10, kain saring, jangka sorong digital, inkubator WTC Binder, pipet ukur, ose bulat, mikro pipet Fisherbrand, paperdisk, $\mathrm{pH}$ meter Eutech Instruments, viskometer Ostwald, handschoen, masker, pisau, blender, dan spidol.

\section{Metode: \\ Persiapan Simplisia Kulit Nanas}

Sebanyak 25 buah, buah nanas disiapkan dan dipisahkan antara buah dan kulitnya. Selanjutnya kulit buah nanas dicuci dengan air mengalir dan dipotong kecil-kecil. Kulit nanas ditimbang sebanyak $13 \mathrm{~kg}$, selanjutnya dilakukan proses pengeringan selama 4 hari menggunakan oven suhu $40^{\circ} \mathrm{C}$. Dari proses pengeringan akan diperoleh simplisia kering dan selanjutnya dihaluskan menggunakan blender serta dilakukan proses pengayakan menggunakan ayakan ukuran 60 mesh. 


\section{Penetapan Kadar Air Simplisia}

Pada penetapan kadar air simplisia diawali dengan proses pengeringan cawan porselin menggunakan oven suhu $105^{\circ} \mathrm{C}$ selama 30 menit. Cawan porselin didinginkan dalam desikator dan ditimbang sampai diperoleh bobot konstan. Sebanyak 1 gram serbuk simplisia kulit nanas dimasukkan ke dalam cawan porselin dan dipanaskan pada suhu $105^{\circ} \mathrm{C}$ selama 6 jam, lalu didinginkan dalam desikator dan ditimbang sampai diperoleh bobot konstan. Penentuan persentase kadar air dilakukan berdasarkan pada penentuan jumlah bobot kering sampel dengan menggunakan rumus sebagai berikut:

$\%$ kadar air $=\frac{\mathrm{A}-\mathrm{B}}{\mathrm{A}} \times 100 \%$

Keterangan: $\mathrm{A}=$ Bobot sampel sebelum pemanasan $(\mathrm{g})$ pemanasan $(\mathrm{g})$

$\mathrm{B}=$ Bobot sampel setelah

\section{Ekstraksi Bonggol Nanas}

Serbuk simplisia kulit buah nanas halus ditimbang sebanyak 1330 gram. Selanjutnya dilakukan ekstrasi menggunakan metode

\section{Formulasi Obat Kumur}

Formula yang digunakan dalam pembuatan obat kumur ekstrak kulit buah nanas dilampirkan pada Tabel 1. maserasi. Pelarut yang digunakan dalam proses maserasi ini adalah etanol $96 \%$ sebanyak 1,33 liter.

Proses maserasi dilakukan dalam kurun waktu 3 hari serta diaduk sesekali. Filtrat yang dihasilkan kemudian diuapkan untuk menghilangkan pelarut yang masih ada menggunakan Rotary Vacum Evaporator suhu $60^{\circ} \mathrm{C}$ sehingga didapatkan ekstrak kental, selanjutnya dilakukan perhitungan rendemennya dengan membandingkan bobot awal simplisia dan ekstrak yang dihasilkan dengan menggunakan rumus sebagai berikut:

\%rendemen ekstrak total $=$

$\frac{\text { Bobot ekstrak yang diperoleh }}{\text { Bobot simplisia }} \times 100 \%$

\section{Penapisan Fitokimia}

Proses ini dilakukan dengan tujuan mendapatkan informasi mengenai senyawa kimia yang terkandung dalam kulit buah nanas. Identifikasi golongan senyawa kimia yang akan dilakukan meliputi alkaloid, saponin, tanin, fenolik, flavonoid, triterpenoid/steroid, dan glikosida.

Tabel 1. Formulasi Sediaan Obat Kumur Ekstrak Kulit Buah Nana

\begin{tabular}{lllll}
\hline Bahan & F1 & F2 & F3 & Fungsi \\
\hline Ekstrak kulit buah nanas & $30 \%$ & $40 \%$ & $50 \%$ & Antibakteri \\
Mentol & $0,5 \%$ & $0,5 \%$ & $0,5 \%$ & Perasa \\
Natrium benzoat & $0,2 \%$ & $0,2 \%$ & $0,2 \%$ & Pengawet \\
Gliserin & $2,5 \%$ & $2,5 \%$ & $2,5 \%$ & Humektan \\
Etanol (95\%) & $1 \%$ & $1 \%$ & $1 \%$ & Pelarut \\
Natrium bikarbonat & $1,7 \%$ & $1,7 \%$ & $1,7 \%$ & Buffer \\
Natrium sakarin & $0,2 \%$ & $0,2 \%$ & $0,2 \%$ & Pemanis \\
Akuades (ad) & $100 \%$ & $100 \%$ & $100 \%$ & Pelarut \\
\hline
\end{tabular}

Sumber: Novero, 2014; Nurhadi, 2015 (telah dimodifikasi)

Keterangan :

F1 = Formulasi sediaan obat kumur 1

$\mathrm{F} 2=$ Formulasi sediaan obat kumur 2

F3 = Formulasi sediaan obat kumur 3 


\section{Pengujian Aktivitas Antibakteri Sediaan Obat Kumur Ekstrak Kulit Nanas}

Bakteri S. sanguinis disuspensikan ke dalam media Nutrient Broth. Sebanyak $10 \mu \mathrm{l}$ suspensi bakteri dari media Nutrient Broth dimasukkan ke dalam $100 \mathrm{ml}$ media Nutrie cair, kemudian dikocok sampai homogen. Setelah itu, dituang ke dalam cawan petri steril.

Setiap cawan dibagi menjadi 5 bagian untuk pengujian antibakteri untuk semua konsentrasi yaitu $30 \%, 40 \%, 50 \%$, serta obat komersial sebagai kontrol positif, dan konsentrasi 0\% (formulasi tanpa ekstrak kulit nanas) sebagai kontrol negatif, kemudian didiamkan hingga padat. Setelah padat, diambil kertas cakram steril, diletakkan di atas permukaan media Nutrient Agar yang sudah ditanambiakkan bakteri Streptococcus sanguinis. Sampel diambil sebanyak $10 \mu \mathrm{l}$ dan diteteskan di atas kertas cakram. Biakan uji diinkubasi di dalam inkubator pada suhu $37^{\circ} \mathrm{C}$ selama 24 jam serta diukur diameter zona bening (clear zone) di sekitar cawan petri menggunakan jangka sorong pada 4 titik dan diambil rata-ratanya.

\section{Evaluasi Sediaan Obat Kumur}

Pada sediaan obat kumur ekstrak etanol bonggol nanas dilakukan evaluasi meliputi pengujian organoleptis, $\mathrm{pH}$ dan pengujian Viskositas.

\section{HASIL DAN PEMBAHASAN}

\section{Penetapan Kadar Air Simplisia Kulit Nanas}

Kandungan air yang dihasilkan dari serbuk simplisia kulit buah nanas sebesar 7,02\%, dan hasil ini memenuhi persyaratan menurut farmakope. Menurut Farmakope Indonesia Edisi IV (1995), kadar air simplisia tidak boleh melebihi $10 \%$ dimaksudkan untuk menghindari pertumbuhan mikroorganisme yang dapat merusak simplisia selama penyimpanan.

\section{Ekstraksi Bonggol Nanas}

Serbuk simplisia kulit nanas diekstraksi dengan metode maserasi menggunakan pelarut etanol $96 \%$. Beberapa keuntungan menggunakan metode maserasi karena dapat digunakan untuk bahan yang terkandung dalam simplisia yang kemungkinan tidak tahan pemanasan serta banyak digunakan untuk mengekstrak senyawa yang mudah larut dalam pelarut yang digunakan (Rene, 2011).

Pada penelitian ini digunakan pelarut etanol 96\% karena etanol merupakan salah satu pelarut yang dapat memberikan hasil yang baik dalam proses ekstraksi senyawa, selain itu diketahui bahwa etanol merupakan pelarut polar dengan tingkat polaritas yang tinggi sehingga mempunyai kemampuan mengekstrak senyawasenyawa yang tingkat kepolarannya tinggi. Flavonoid, glikosida, saponin, tanin dan beberapa alkaloid merupakan senyawa yang dapat dilarutkan oleh etanol (Sarker et al., 2006). Pelarut etanol 96\% sangat efektif digunakan pada proses ekstraksi kulit buah nanas karena dari penelitian terdahulu diketahui bahwa senyawa yang terkandung dalam kulit buah nanas yang mempunyai aktivitas antibakteri bersifat polar (Voight, 1994). Menurut Harbone 1987, faktor penting pada pemilihan pelarut pengekstrak adalah kemampuan untuk mengekstrak, tidak bersifat racun dan kemudahan untuk diuapkan. Pada penelitian ini, serbuk simplisia yang diekstrak sebanyak 1330 gram dan diperoleh ekstrak kental sebanyak 132,4 gram serta diperoleh rendemen sebesar $9,95 \%$.

\section{Hasil Penapisan Fitokimia}

Penapisan fitokimia yang dilakukan yaitu uji alkaloid, saponin, tanin, fenolik, flavonoid, triterpenoid, steroid, dan glikosida. Hasil penapisan fitokimia ekstrak kulit nanas dapat dilihat pada Tabel 2.

Tabel 2. Hasil Penapisan Fitokimia Ekstrak Kulit Nanas

\begin{tabular}{llll}
\hline \multicolumn{1}{c}{ Uji } & Reagen & Hasil & \multicolumn{1}{c}{ Keterangan } \\
\hline Alkaloid & & & \\
& Bouchardat & + & Endapan cokelat-hitam \\
Saponin & Dragendorf & + & Endapan merah bata \\
Tanin & & + & Terbentuk buih/busa \\
Fenolik & & + & Warna hitam \\
Flavonoid & & - & - \\
Triterpenoid & & + & Warna orange/jingga \\
Steroid & + & Warna hijau \\
Glikosida & & + & Warna hijau \\
\hline
\end{tabular}

Keterangan: (+) positif/ada, (-) negatif/tidak ada 
Hasil Uji Aktivitas Antibakteri Ekstrak Kulit Nanas Dan Sediaan Obat Kumur Ekstrak Kulit Nanas

Untuk menguji aktivitas antibakteri digunakan metode difusi cakram berdasarkan pada pengukuran diameter zona bening penghambatan pertumbuhan bakteri yang terbentuk di sekeliling kertas cakram menggunakan jangka sorong (caliper). Pengujian aktivitas antibakteri dilakukan pada ekstrak kulit nanas dan sediaan obat kumur ekstrak kulit nanas. Sebagai kontrol positif digunakan chlorhexidine base. Pengujian aktivitas antibakteri dilakukan pada 3 kelompok perlakuan dan 2 kelompok kontrol dengan 3 kali ulangan pada masing-masing kelompok. Pada penelitian ini, kelompok perlakuan terdiri dari ekstrak kulit nanas dan sediaan obat kumur ekstrak kulit nanas dengan masing-masing konsentrasi 30\%, 40\%, dan 50\%. Hasil uji aktivitas antibakteri ekstrak kulit nanas terhadap bakteri Streptococcus sanguinis dapat dilihat pada Tabel 3 dan Gambar 1.

Tabel 3. Hasil Uji Aktivitas Antibakteri Ekstrak Kulit Nanas Terhadap Pertumbuhan Bakteri Streptococcus sanguinis

\begin{tabular}{lllll}
\hline Perlakuan & \multicolumn{5}{l}{ Luas Zona Bening $(\mathbf{m m})$} \\
\hline & I & II & III & Rata-rata \\
\hline Konsentrasi 30\% & 11,27 & 11,35 & 11,31 & 11,31 \\
Konsentrasi 40\% & 13,11 & 12,94 & 13,22 & 13,09 \\
Konsentrasi 50\% & 14,98 & 15,02 & 15,09 & 15,03 \\
Kontrol Positif & 18,13 & 18,09 & 18,05 & 18,09 \\
Kontrol Negatif & - & - & - & - \\
\hline
\end{tabular}

Keterangan : diameter paperdisk $=6 \mathrm{~mm}$

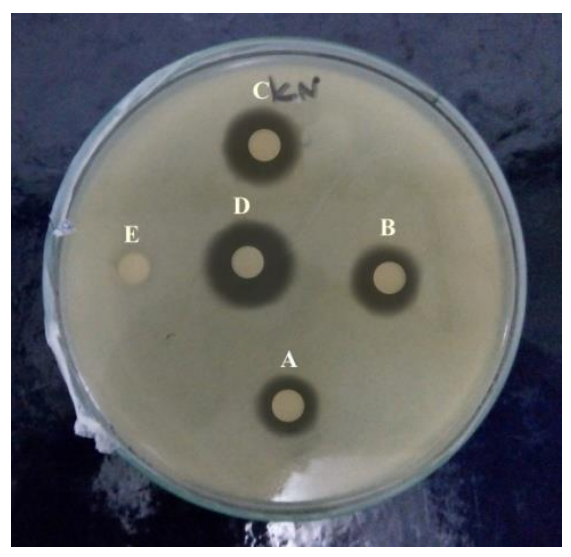

\section{Gambar 1. Hasil Uji Aktivitas Antibakteri Ekstrak Kulit Nanas Terhadap pertumbuhan Bakteri Streptococcus sanguinis}

Keterangan: $\mathrm{A}=$ konsentrasi $30 \%, \mathrm{~B}=$ konsentrasi $40 \%, \mathrm{C}=$ konsentrasi $50 \%, \mathrm{D}=\mathrm{kontrol}$ positif, dan $\mathrm{E}=\mathrm{kontrol}$ negatif

Gambar 1 memperlihatkan adanya zona bening yang terbentuk dan ini menunjukkan bahwa sampel mempunyai khasiat penghambatan perkembangbiakan bakteri Streptococcus sanguinis. Berdasarkan klasifikasi respon hambat pertumbuhan bakteri, tersebut didapatkan hasil bahwa semua konsentrasi ekstrak kulit nanas memiliki aktivitas antibakteri terhadap pertumbuhan Streptococcus sanguinis dan memberikan nilai diameter hambat lebih dari $10 \mathrm{~mm}$ dan termasuk ke dalam kategori kuat pada semua konsentrasi yaitu konsentrasi ekstrak 30\%, 40\% dan 50\%.

Selanjutnya pada formulasi obat kumur ekstrak etanol kulit buah nanas dilakukan uji aktivitas terhadap bakteri Streptococcus 
20 | Triyani Sumiati et al., (Formulasi Obat Kumur Herbal Ekstrak Etanol...)

sanguinis dan hasil dapat dilihat pada Tabel 4

dan Gambar 2.

Tabel 4. Hasil Uji Aktivitas Antibakteri Sediaan Obat Kumur Ekstrak Kulit Nanas Terhadap Pertumbuhan Bakteri Streptococcus sanguinis

\begin{tabular}{lllll}
\hline \multirow{2}{*}{ Perlakuan } & \multicolumn{3}{l}{ Luas Zona Bening $(\mathbf{m m})$} & \\
\cline { 2 - 5 } & I & II & III & Rata-rata \\
\hline Konsentrasi 30\% & 9,87 & 9,96 & 9,94 & 9,92 \\
Konsentrasi 40\% & 11,33 & 11,48 & 11,35 & 11,39 \\
Konsentrasi 50\% & 12,47 & 12,51 & 12,54 & 12,51 \\
Kontrol Positif & 15,77 & 15,68 & 15,71 & 15,72 \\
Kontrol Negatif & - & - & - & - \\
\hline
\end{tabular}

Keterangan : diameter paperdisk $=6 \mathrm{~mm}$

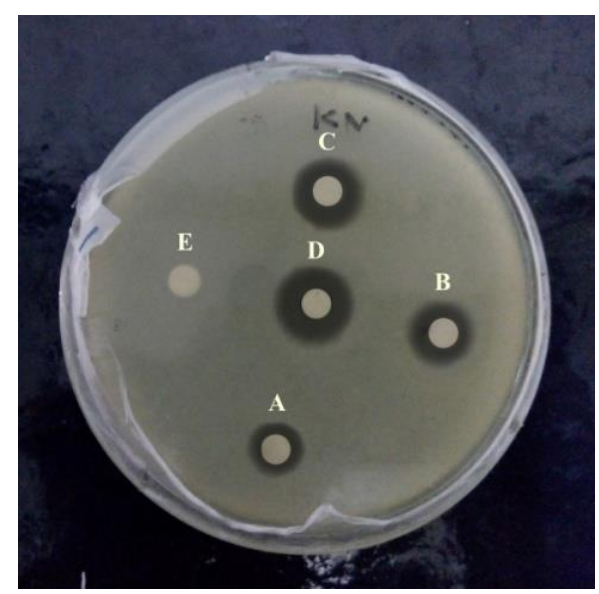

Gambar 2. Hasil Uji Aktivitas Antibakteri Sediaan Obat Kumur Ekstrak Kulit Nanas Terhadap Pertumbuhan Bakteri Streptococcus sanguinis

Keterangan: $\mathrm{A}=$ konsentrasi 30\%, $\mathrm{B}=$ konsentrasi $40 \%, \mathrm{C}=$ konsentrasi $50 \%, \mathrm{D}=$ kontrol positif, dan $\mathrm{E}=\mathrm{kontrol}$ negatif

Gambar 2 memperlihatkan adanya zona bening yang terbentuk dan ini menunjukkan bahwa sampel mempunyai khasiat penghambatan perkembangbiakan bakteri Streptococcus sanguinis. Dari hasil penelitian diperoleh bahwa sediaan obat kumur ekstrak kulit nanas memiliki aktivitas antibakteri terhadap pertumbuhan Streptococcus sanguinis pada semua konsentrasi. Sediaan dengan kadar $30 \%$ mempunyai diameter $9,92 \mathrm{~mm}$ dan hal ini menunjukkan daya antibaketri kategori sedang.
Sedangkan pada konsentrasi $40 \%$ dan $50 \%$ memberikan nilai diameter hambat lebih dari 10 $\mathrm{mm}$ dan hal ini menunjukkan bahwa pada konsentrasi tersebut termasuk ke dalam kategori kuat. Hasil perbandingan uji aktivitas antibakteri ekstrak kulit nanas dan sediaan obat kumur ekstrak kulit nanas terhadap pertumbuhan bakteri Streptococcus sanguinis dapat dilihat pada Gambar 3. 


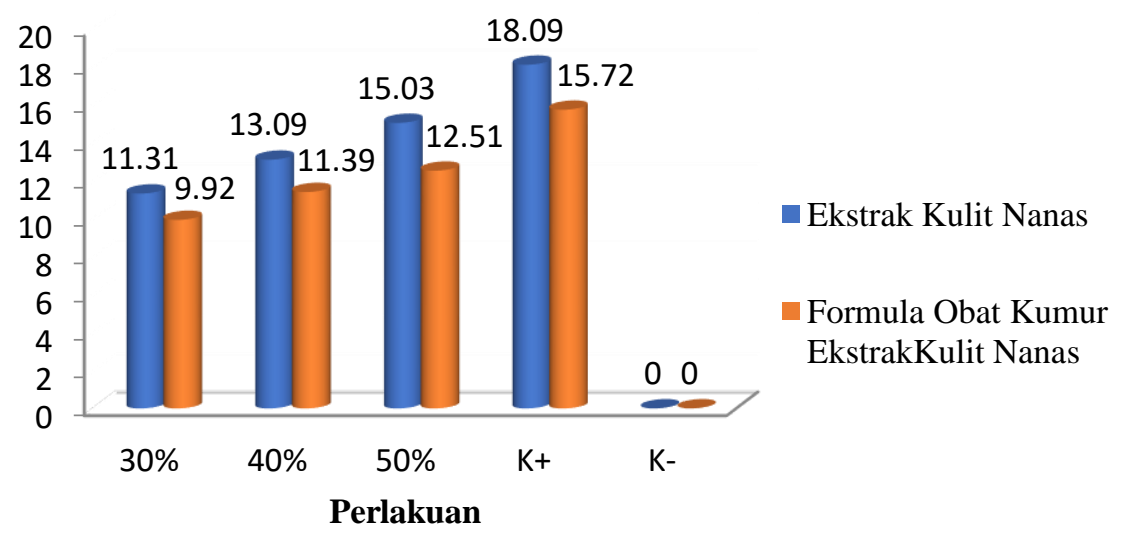

\title{
Gambar 3. Grafik Perbandingan Diameter Zona Bening Bakteri Ekstrak Kulit Nanas dan Sediaan Obat Kumur Ekstrak Kulit Nanas
}

\author{
Keterangan : $\mathrm{K}(+)=$ kontrol positif, $\mathrm{K}(-)=$ kontrol negatif
}

Pada penelitian ini dihasilkan bahwa terjadi penurunan aktivitas antibakteri pada ekstrak kulit nanas setelah dibuat menjadi sediaan obat kumur. Kemungkinan hal ini terjadi karena adanya reaksi kimia antara senyawa metabolit sekunder ekstrak kulit nanas dengan bahanbahan yang ditambahkan ke dalam sediaan obat kumur sehingga dapat mempengaruhi atau menurunkan aktivitas antibakteri dari ekstrak kulit nanas. Zona bening yang dihasilkan baik dari ekstrak kulit nanas maupun formulasi sediaan obat kumur ekstrak buah nanas diperoleh bahwa dengan meningkatnya konsentrasi ekstrak menunjukkan hubungan semakin besar daya hambat antibakterinya. Hal ini sejalan dengan penelitian Pelczar dan Chan (2005) yang menyatakan bahwa semakin tinggi konsentrasi suatu bahan antibakteri maka aktivitas antibakterinya semakin kuat. Hasil ini juga sejalan dengan pernyataan Roslizawaty et al., (2013), bahwa efektivitas suatu zat antibakteri dipengaruhi oleh konsentrasi zat tersebut.

Kemampuan ekstrak kulit nanas dalam menghambat pertumbuhan bakteri Streptococcus sanguinis dikarenakan adanya senyawa kimia yang terkandung di dalam ekstrak kulit nanas. Berdasarkan hasil penapisan fitokimia, kulit nanas mengandung senyawa alkaloid, saponin, tanin, flavonoid, triterpenoid, steroid, dan glikosida. Dari hasil penelitian sebelumnya, telah diketahui bahwa senyawa kimia yang berpotensi sebagai antibakteri dalam kulit nanas adalah flavonoid dan tanin (Annisa, 2015; Setiawan, 2015).

\section{Hasil Evaluasi Sediaan Obat Kumur Ekstrak Kulit Nanas \\ Pengamatan Organoleptik}

Pada penelitian ini pengamatan organoleptik obat kumur meliputi pengamatan aroma, rasa, dan warna. Pengamatan dilakukan pada minggu ke-0 sampai dengan minggu ke-4. Hasil pengamatan organoleptik obat kumur ekstrak kulit nanas pada setiap minggunya tidak menunjukkan adanya perubahan baik aroma, rasa, maupun warna. Seluruh sediaan obat kumur yang dibuat tetap stabil dalam penyimpanan pada suhu kamar selama 4 minggu. Dari hasil pengamatan warna didapatkan hasil bahwa warna obat kumur akan semakin pekat dengan kenaikan konsentrasi. Perbedaan warna tersebut dikarenakan adanya perbedaan konsentrasi ekstrak kulit nanas yang ditambahkan. Warna pada formula 1 berwarna orange muda, formula 2 berwarna orange kecokelatan, dan formula 3 berwarna cokelat. Aroma yang dihasilkan dari seluruh sediaan obat kumur adalah bau khas nanas serta ada sedikit bau mint yang berasal dari mentol. Rasa yang dihasilkan dari seluruh obat kumur adalah asam khas nanas dan agak sedikit pedas karena adanya kandungan mentol yang ditambahkan sebagai perasa. 


\section{Pengukuran pH}

Pada penelitian ini, hasil pengukuran $\mathrm{pH}$ obat kumur setiap minggunya tidak memberikan perubahan hasil yang berbeda dimana $\mathrm{pH}$ yang dihasilkan menunjukkan range $\mathrm{pH}$ dari 5,946,45 , nilai $\mathrm{pH}$ yang dihasilkan mendekati nilai
pH obat kumur komersial yaitu sebesar 6,51 dan sesuai dengan nilai $\mathrm{pH}$ sediaan untuk obat kumur mulut yang ada di pasaran pada umumnya sekitar 5-7 (Soesilo et al., 2005). Hasil dapat pengukuran $\mathrm{pH}$ dapat dilihat pada gambar 4.

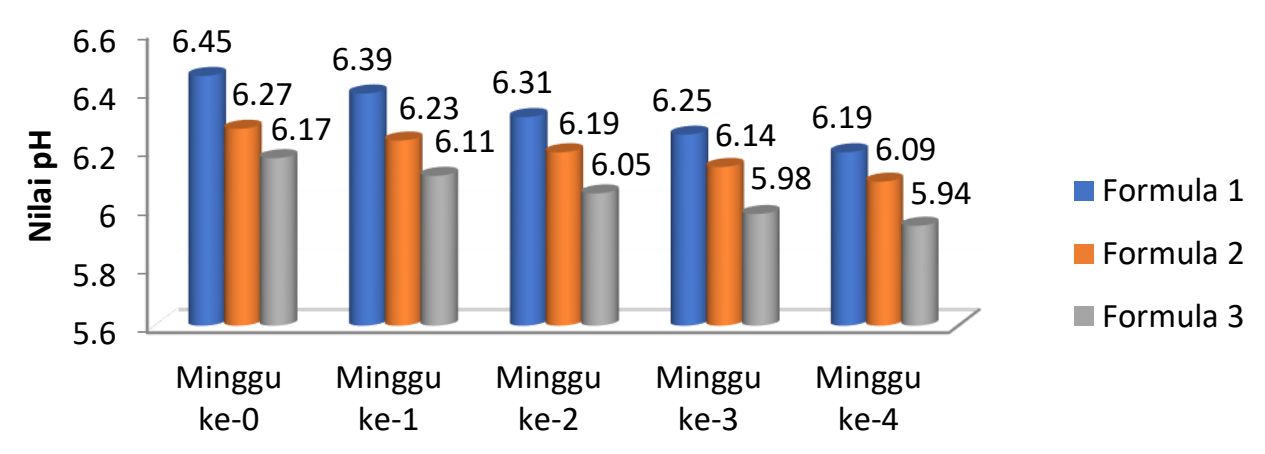

Lama Penyimpanan

\section{Gambar 4 Grafik Nilai pH Obat Kumur Selama Penyimpanan}

\section{Pengukuran Viskositas}

Pada penelitian ini, hasil pengukuran viskositas menunjukkan bahwa ketiga formulasi obat kumur memiliki nilai viskositas rendah berkisar antara 1,23-1,86 cps. Nilai yang dihasilkan ini dimana mendekati nilai viskositas obat kumur komersial sebesar 1,03 cps. Viskositas pada seluruh sediaan obat kumur tidak mengalami perubahan yang signifikan setiap minggunya. Hal ini menunjukkan bahwa sediaan obat kumur memiliki viskositas yang stabil selama penyimpanan. Hasil pengukuran viskositas dapat dilihat pada gambar 5 .

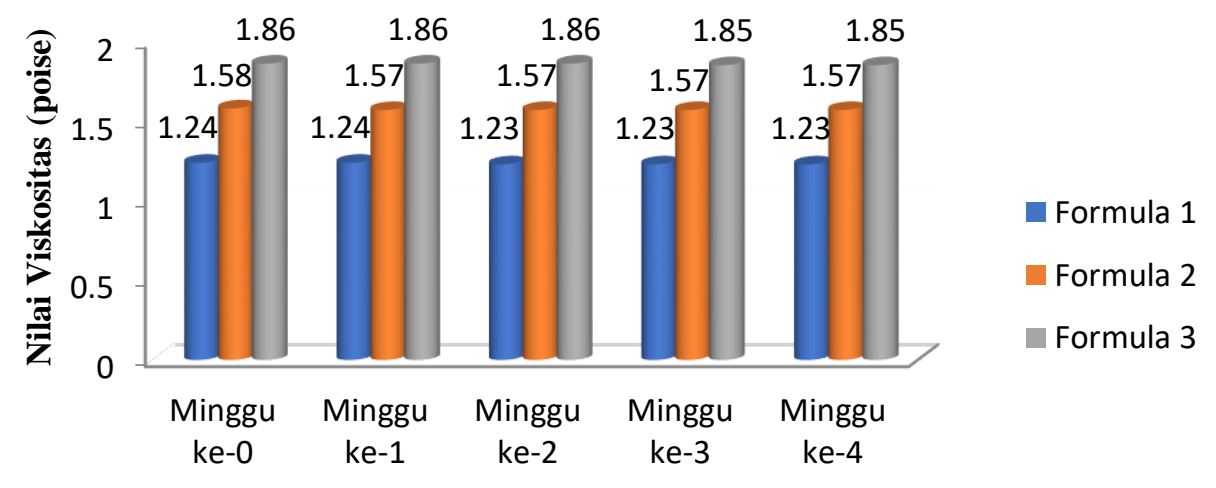

Lama Penyimpanan

\section{Gambar 5. Grafik Nilai Viskositas Obat Kumur Selama Penyimpanan}

\section{KESIMPULAN}

1. Ekstrak etanol kulit buah nanas dapat diformulasikan menjadi sediaan obat kumur dan mempunyai daya antibakteri sedang pada konsentrasi $30 \%$ dengan nilai rata-rata diameter zona bening $9,92 \mathrm{~mm}$ serta daya antibakteri kuat pada konsentrasi $40 \%$ dan $50 \%$ berturut-turut sebesar $11,39 \mathrm{~mm}$ dan $12,51 \mathrm{~mm}$.
2. Berdasarkan evaluasi sediaan, obat kumur ekstrak etanol kulit buah nanas telah memenuhi persyaratan sesuai dengan obat kumur komersial dan stabil pada penyimpanan.

3. Ekstrak kulit nanas mempunyai aktivitas antibakteri lebih besar dibandingkan dengan sediaan obat kumur ekstrak kulit nanas. Daya antibakteri terbesar pada ekstrak etanol kulit buah nanas konsentrasi 
23 | Triyani Sumiati et al., (Formulasi Obat Kumur Herbal Ekstrak Etanol...)

$50 \%$ dengan diameter zona bening 15,03 mm dan pada sediaan obat kumur ekstrak etanol kulit buah nanas pada konsentrasi $50 \%$ dengan diameter zona bening 12,51 $\mathrm{mm}$.

\section{DAFTAR PUSTAKA}

[1] Annisa, A. 2015. Uji Efektivitas Antibakteri Ekstrak Kulit Nanas (Ananas comosus L.) Terhadap Pertumbuhan Streptococcus Mutans Penyebab Karies Gigi [skripsi]. Padang: Fakultas Kedokteran Gigi Universitas Andalas Padang.

[2] [Depkes] Departemen Kesehatan. 1979. Farmakope Indonesia Edisi III. Jakarta: Departemen Kesehatan Republik Indonesia.

[3] [Depkes] Departemen Kesehatan. 1995. Farmakope Indonesia Edisi IV. Jakarta: D epartemen Kesehatan Republik Indonesia.

[4] Harborne, J.B. 1987. Metode Fitokimia. Edisi 2. Padmawinata., penerjemah. Bandung: Institut Teknologi Bandung.

[5] Jannata, R.H., Gunadi, A., Ermawati, T. 2014. Daya Antibakteri Ekstrak Kulit Apel Manalagi (Malus sylvestris Mill.) Terhadap Pertumbuhan Streptococcus mutans. $e$ Jurnal Pustaka Kesehatan 2(1): 23-28.

[6] Lu, X.H., Sun, D.Q., Wu, Q.S., Liu, S.H., Sun, G.M. 2014. Physico Chemical Properties, Antioxidant Activity and Mineral Contents of Pineapple Genotypes Grown in China. Molecules. Page 85188532.

[7] Novero, A. 2014. Formulasi Obat Kumur Antiseptik Ekstrak Daun Salam (Eugenia polyantha Wight) [skripsi].

[8] Nuraini, D.S. 2011. Aneka Manfaat Kulit Buah dan Sayuran. Yogyakarta: Andi

[9] Nurhadi, G. 2015. Pengaruh Konsentrasi Tween 80 Terhadap Stabilitas Fisik Obat Kumur Minyak Atsiri Herba Kemangi (Ocimum americanum L.) [skripsi]. Jakarta: Fakultas Kedokteran dan Ilmu Kesehatan UIN Syarif Hidayatullah.

[10] Padmon, S.H., Hasan, H., Tungadi., R. 2013. Formulasi Dan Evaluasi Ekstrak
Bunga Cengkeh (Syzygium aromaticum L.) Dalam Bentuk Sediaan Mouthwash.

[11] Pelczar, M.J., Chan, E.C.S. 2005. Dasardasar Mikrobiologi 2. Hadioetomo R.S., Imas T., Tjitrosomo S.S., Angka S.L., penerjemah. Jakarta: Universitas Indonesia Press. Hlm: 450,

[12] Rene, N.M.L. 2011. Mempelajari Ekstraksi Pigmen Antosianin dari KulitManggis dengan Berbagai Jenis Pelarut. Bandung: Universitas Pasundan

[13] Roslizawaty et al. 2013. Aktivitas Antibakterial Ekstrak Etanol dan Rebusan Sarang Semut (Myrmecodia sp.) terhadap Bakteri Escherichia coli. Jurnal Medika Veterinaria 7(2): 91-94.

[14] Sarker, D., Latif, Z., Gray, I., Alexander. 2006. Natural Product Isolation. New J ersey: Humana Press.

[15] Setiawan, M.H. 2015. Isolasi Dan Uji Daya Antimikroba Ekstrak Kulit Nanas (Ananas comosus L. Merr) [skripsi]. Semarang: Fakultas Matematika dan Ilmu Pengetahuan Alam Universitas Negeri Semarang.

[16] Silva, D.D., Goncalo, C.S., Sousa, M.L.R., Wada, R.S. 2004. Aggregation of plaque disclosing agent in a dentifrice. Journal of Applied Oral Science 12(2): 154-8.

[17] Soesilo, D., Erlyawati, S., Rinna, Diyatri, I. 2005. Peranan sorbitol dalam mempertahankan kestablian $\mathrm{pH}$ saliva pada proses pencegahan karies. Majalah Kedokteran Gigi (Dental Journal) 38(1): 25-28.

[18] Voight, R. 1994. Buku Pelajaran Teknologi Farmasi Edisi V. Yogyakarta: Universitas Gajah Mada Press.

[19] Yamaguchi, M. et al. 2006. Role of Streptococcus sanguinis Sortase A In Bacterial Colonization. Elsevier Masson: 2791. 